avoidable faults in the preparation and preservation of foods. Emphasis in prevention is laid upon adequate heat treatment of commercially canned meats; adequate sealing of tins; sufficient heating of home-preserved vegetables and fruits, especially the non-acid variety; and the discouragement of local customs which favour the eating of preserved foods in an uncooked state in the form of salads, watery conserves, poorly cured or inadequately smoked pork, and salted-fish products. It is worth mentioning that horses, cattle, sheep, chickens, and ducks may suffer botulism through eating badly preserved fodder or silage, or carrion. (For a brief but useful review see Wilson \& Miles, I955, p. I824).

\title{
REFERENCES
}

Anderson, P. H. R. \& Stone, D. M. (1955). Y. Hyg., Camb., 53, 387 .

Collee, J. G. (1954). भ. R. Army med. Cps, 100, 296.

Dack, G. M. (1956). Food Poisoning, 3rd. ed. London: Cambridge University Press.

Hobbs, B. C. (1954). Food Sci. Abstr, 26, 601.

Hobbs, B. C. \& Smith, M. E. (1954). F. Hyg., Camb., 52, 230.

Hobbs, B. C., Smith, M. E., Oakley, C. L., Warrack, G. H. \& Cruickshank, J. C. (1953). J. Hyg., Camb., 51,75 .

Knox, R. \& Macdonald, E. K. (1943). Med. Offr, 69, 2 I,

Leighton, G. R. (1923). Report to the Scottish Board of Health. London: H.M. Stationery Office.

McClung, L. S. (I945). Y. Bact. 50, 229.

McCullough, N. B. \& Eisele, C. W. (I95 1 a). F. infect. Dis. 88, 278.

McCullough, N. B. \& Eisele, C. W. (I95Ib). F. infect. Dis. 89, 209.

McCullough, N. B. \& Eisele, C. W. (I95Ic). F. infect. Dis. 89, 259.

Meyer, K. F. (1956). Bull. World Hlth Org. 15, 281.

Oakley, C. L. (1949). Brit. med. F. i, 269.

Oakley, C. L. \& Warrack, G. H. (1953). F. Hyg., Camb., 51, 102.

Public Health Laboratory. Service (1956), Mon. Bull. Minist. Hlth Lab. Serv. 15, 263.

Savage, W. (1956). Brit. med. F. ii, 317.

Smith, J. \& Wallace, J. M. (1956). Hlth Bull, Edinb., I4, 3 r.

Society for Applied Bacteriology (1955). Symposium on Food Microbiology and Public Health, published in 7 . appl. Bact. 18, 462-629.

Wilson, G. S. \& Miles, A. A. (I955). Topley and Wilson's Principles of Bacteriology and Immunity, 4th ed. Vol. 2. London: Edward Arnold (Publishers) Ltd.

Zeissler, J. \& Rassfeld-Sternberg, L. (I949). Brit. med. F. i, 267.

\section{Inspection of food}

\section{By H. B. PARRY, Chief Sanitary Inspector, The City of Aberdeen}

In this age of progress it would indeed be surprising if food-inspection technique had not also undergone change. Yet, it is true to say that many of the basic principles of food inspection have only required modification to keep pace with some new food treatments. Other instances, however, demand such highly specialized and detailed knowledge that fair controlling legislation can only be made after consultations with scientists, doctors, bacteriologists, dietitians, analysts, veterinarians and inspectors.

I will refer first to three definitions in my paper.

(I) 'Food' means food as defined in the Food and Drugs Act 1955 and Food and Drugs (Scotland) Act I956, i.e. 'food' includes drink, chewing gum and other 
products of a like nature and use, and articles and substances used as ingredients in the preparation of food or drink or of such products, but does not include (a) water, live animals or birds; (b) fodder or feeding-stuffs for animals, birds or fish; or (c) articles or substances used only as drugs.

(2) 'Drug' (also taken from the two preceding Acts) includes medicine for internal or external use.

(3) 'Safe food' is taken to mean unadulterated food that is free from contamination, harmful organisms or other injurious substances.

At this stage, it may be advisable to state that it is the intention to deal with the subject in as practicable a manner as possible and thus avoid frequent references to many of the relative Acts, Orders, Regulations and official publications on the subject of food control.

\section{Objective : safe food}

The food inspector's first concern is with the examination and sampling of some foods which experience has taught us are most likely to be the vehicles for the transmission of infection and illness to mankind.

\section{Milk}

Since April 1952, the County of the City of Aberdeen has been a Specified Area for the purpose of the Milk (Special Designations) Act 1949, and consequently it is an offence to sell by retail any non-designated milk in the area. Milk is sampled at the place of production, at the dairy, or in course of delivery, and must comply with the Milk (Special Designations) (Scotland) Orders 1951/52, the main retail provisions of which are summarized below as follows.

Pasteurized milk. (i) Must comply with the phosphatase test, i.e. to give a reading not exceeding 2.3 Lovibond blue units; (ii) must contain no coliform bacteria in $0.0 \mathrm{r}$ ml.; (iii) must be bottled at premises where pasteurized; (iv) must be labelled 'Pasteurised', must bear the name of the premises, and bottle caps must overlap bottle lips.

Certified milk. (i) Must be derived from an attested herd; or (ii) from a herd in a tuberculosis-eradication area or from a herd in a designated attested area and be subject to other specific controls as laid down in the 195I Order; (iii) the special designation shall not be used in relation to milk from an animal showing evidence of disease which is likely to injuriously affect the milk; (iv) must be put into the retail containers on the producer's premises and may bear the words 'Farm Bottled'; (v) caps must overlap the lips of the bottles and bear the words 'Certified Milk' and the name of the producer's premises; (vi) must not be treated by heat, or in any manner likely to affect its nature or qualities; (vii) must contain no coliform bacteria in $0.1 \mathrm{ml}$.; (viii) must contain no more than 30,000 bacteria $/ \mathrm{ml}$.

Tuberculin-tested milk (i) Paragraphs (i) (ii) (iii) and (vi) relative to Certified Milk apply; (ii) need not be put into retail containers at the place of production; (iii) retail container caps must bear the bottling address and the words 'Tuberculin 
Tested Milk', and bottle caps must overlap bottle lips; (iv) must contain not more than $200,000 \mathrm{bacteria} / \mathrm{ml}$. and (v) no coliform bacteria in $0.01 \mathrm{ml}$.

Sterilized milk. (i) Shall be filtered or clarified and homogenized before sterilization; (ii) shall be sterilized in capped bottles and hermetically sealed on completion of treatment; (iii) shall be heated to and maintained for a period not exceeding $30 \mathrm{~min}$ at a temperature of not less than $220^{\circ} \mathrm{F}$. and not more than $235^{\circ} \mathrm{F}$; (iv) every bottle shall bear the words 'Sterilised Milk' and the name of the premises where sterilization was carried out; (v) shall satisfy the turbidity test.

Additional tests. (I) Routine bacteriological samples of raw milk are also taken at the producer's premises and submitted for biological examination. (2) (a) All milks are also submitted for compositional analysis in accordance with the Sale of Milk Regulations Igor. (Milk is to be presumed, until the contrary is proved, to be not genuine if it contains less than $3 \%$ milk fat or less than $8.5 \%$ milk solids other than milk fat.) (b) Where milk is sold as Channel Islands, Jersey, Guernsey or South Devon Milk, it shall contain not less than $4 \%$ milk fat. (3) Examination is also carried out under the Food and Drugs (Scotland) Act 1956, as it is an offence to (a) add any water or colouring matter or any dried or condensed milk or liquid reconstituted therefrom to milk intended for sale for human consumption; or (b) add any separated milk, or mixture of cream and separated milk, to unseparated milk intended for such sale; or (c) sell or offer or expose for sale, or have for the purpose of sale for human consumption any milk to which any addition has been made in contravention of (a) or (b) above.

It is also an offence for a person to sell, offer or expose for sale, or have for the purpose of sale as milk, any liquid in the making of which any separated milk or any dried or condensed milk is used.

\section{Ice-cream}

(i) The food inspector should also be responsible for the inspection of the related food-processing equipment. This is particularly desirable with milk and meat products, as most contamination or adulteration is the result of so-called handling methods. (ii) Routine checking and sampling of ice-cream for sale is carried out at all premises, whether or not they are exempt from the registration provisions of the Ice Cream (Scotland) Regulations I948. (iii) The product must be heat treated before freezing, i.e. be retained (a) at a temperature not lower than $15^{\circ} \mathrm{F}$. for at least $30 \mathrm{~min}$, or (b) retained at a temperature not lower than $160^{\circ} \mathrm{F}$. for at least Io min. Alternatively, the product may be made by adding water only to a complete 'cold' mix, i.e. a mix which has been suitably heat treated and then dehydrated. This mix must be delivered to the dealer in unopened air-tight containers in which it has been packed by the manufacturer. (iv) Ice-cream is also subjected to various detailed time - temperature controls as laid down in the Regulations; and cleanliness must also be observed. (v) Compositional standards are laid down in the Food Standards (Ice Cream) Order 1953: ice-cream shall contain not less than $5 \%$ fat, I0 $\%$ sugar and $7 \frac{1}{2} \%$ milk solids other than fat. There are also two other standards; one for parev or kosher ice and the other for ice-cream containing any fruit, fruit 
pulp or fruit puree. (vi) Bacteriological standards are recommended in the Department of Health's Memorandum on the Hygienic Control of Premises and Equipment, no. 43 (Tech.) 1948. Samples should not contain more than 100,000 organisms $/ \mathrm{g}$, and coliform organisms should be absent in $0.01 \mathrm{~g}$.

\section{Meat}

General. With the exception of imported meat and other meat in business premises which is inspected as a matter of routine along with other foods under the Food and Drugs (Scotland) Act 1956, or (if at the port) under the Public Health (Imported Food) Regulations (Scotland) 1937-48, all meat is inspected at the slaughterhouses.

The Public Health (Meat) Regulations (Scotland) 1932, as amended in I948, and the Food and Drugs (Scotland) Act 1956 control the inspection arrangements in connexion with all food animals.

Routine inspection. (i) All organs and viscera, together with their lymph glands are examined by observation and palpation, and by incision if necessary. (ii) Carcasses are examined for nutrition, bruising, haemorrhage, discoloration, oedema, efficiency of bleeding, swellings or deformities of bones or joints, or other abnormality of the flesh. The serous membranes are examined and so are the ribs, sternum, vertebrae and spinal cord if the carcass has been split. (iii) The head, tongue and palate are examined; the cheek muscles and retro-pharyngeal lymph glands are incised (with pigs, the submaxillary is incised instead of the retro-pharyngeal). (iv) Stomach, intestines and spleen are next examined and the mesenteric glands incised. (v) Liver, bile ducts and hepatic gland are incised. (vi) Lungs are palpated and incised at the base along with the bronchial and mediastinal glands. (vii) The heart is freed from the pericardium and incised to expose the ventricles. (viii) The renal and adrenal glands are incised and the kidneys freed from the surrounding fat. (ix) Udder and associated supramammary glands are also incised. (x) The surfaces and substance of the reproductive organs are also examined.

Detailed inspection. Where inspection reveals evidence of tuberculosis, a detailed examination is followed as laid down in the Regulations in order to confine the rejected parts to their respective drainage areas as far as possible.

Rejection. The Regulations enumerate the following thirty-three instances when it is necessary to reject the whole carcass and organs as unfit for food: (A) Tuberculosis with emaciation, generalized tuberculosis-as defined in Part IV of the Regulations; actinomycosis, generalized; anaemia (if pronounced); anthrax (cases of this disease must be notified in compliance with the terms of the Diseases of Animals Act); blackleg; bruising, general, extensive and severe, with or without gangrene; Cysticercus cellulosae (measly pork); (N.B. in the examination of all pig carcasses, the 'leaf seam' (subperitoneal fat) shall be raised and the inner surface of the abdominal muscles examined for evidence of Cysticercus cellulosae); decomposition; dropsy, general; emaciation, general pathological; fever; glanders (or farcy) (cases of this disease must be notified in terms of the Diseases of Animals Act); immaturity (i.e. stillborn or unborn carcasses); jaundice; lymphadenitis, caseous-generalized; malignant catarrh; malignant neoplasms, unless localized, 
in situation and effect, to one organ; mammitis, acute septic or gangrenous; melanosis, generalized-or any generalized pigmentation; metritis, acute septic; odour, associated with disease or otherwise prejudicial to health; pericarditis, septic; pneumonia, septic or gangrenous; pyaemia, including joint-ill, or umbilical pyaemia; rickets, with malnutrition; sarcocysts - if generalized in the musculature and visible to the naked eye; septicaemia, or septic intoxication; swine erysipelas, acute; swine fever (cases of this disease must be notified in terms of the Diseases of Animals Act); tetanus; trichinosis; tumours, multiple, in musculature; uraemia. (B) In the event of evidence of Cysticercus bovis (beef measles) being found in a carcass or a head or both, the carcass or the head or both may be passed for human consumption provided that they are placed in cold storage at a temperature not higher than $20^{\circ} \mathrm{F}$. for a period of at least 3 weeks, or, alternatively, they shall be seized. (C) In all cases in which evidence of diseases not enumerated in Instructions (A) and (B) above are found, the organ or portion of the carcass (or organs or portions of the carcass) affected by the disease, and the organs or portions contiguous thereto, shall be seized.

\section{Fish}

Of the various species of fish (shell-fish excluded) there are about sixty-three varieties, including twelve from fresh water which make up the normal trade. Fresh-water fish are legally defined and some are specifically protected by close seasons, but there are no protective seasons for so called ordinary fish.

Inspection at the ports is primarily directed towards the detection of early decomposition caused by organisms penetrating the skin, gills or cavities. Experience has shown that sea fish are remarkably free from disease, although some parasitic conditions exist. Nematodes are commonly found but are mainly removed during gutting. When an individual examination is made, a particular lookout is kept for the presence of the unencapsulated Pleroceroid of Bothriocephalus latus. In the markets it is known that certain species of fish caught in particular waters are liable to parasitic infestations and this is one of the matters at present under investigation by research workers and inspectors.

\section{Other food}

Inspections are also carried out in the streets, shops, markets, hospitals, schools and docks; routine samples may range from lozenges to lollipops, or chewing gum to cream buns.

Imported consignments of food are examined after customs clearance, upon a numerical percentage basis and all stained containers opened. Cans are inspected for signs of reconditioning, pinholing, damaged seams, leaks or blowing.

Food is also submitted for analysis, to check manufacturers' claims which may be made on labels, published in the press, or advertized by leaflet, film or radio. Constituents are compared with any food standards relevant to composition (including vitamins), colouring matter, preservatives, or mineral oil; and to ensure 
compliance with the Food and Drugs Acts, Labelling of Food Orders I953 with Amending (Scotland) Regulations of 1956.

\title{
Some reflections
}

From official reports on food-borne illness, it seems evident that most cases are due to post-mortem or post-milking bacterial contamination by man, animals, or insects. It is expected that the practice of food hygiene will eventually control such infections, but until then, the measurement of progress may be by bacteriological food sampling.

The sanitary inspector has already been given the necessary legal powers which he should use specifically and with the utmost discretion. On the other hand, will the solution be ultimately provided by the use of antibiotics or controlled exposure to radioactive sources? Are we indeed now reaching the age when fish will no longer require inspecting for infections, freshness, or excess preservative, but will be 'frisked' for radioactive contamination from the waters around the nuclear power stations?

\section{The viewpoint of catering management}

By E. W. G. Guest, foint Managing Director, Macvitties Guest and Company

\author{
Limited, Princes Street, Edinburgh
}

I should like to open my remarks by saying that I intend to deal with the subject of 'clean food', and to show the methods used by caterers at the present time to further this aim.

\section{Education in hygiene}

Clean-food hygiene must begin with instructions to the staff as regards clean personal habits, that is, scrupulous attention to washing of hands and finger nails, and to the condition of hair which should always be kept tidy. Caps should be worn, wherever possible, for work in kitchens and other preparation rooms. The present fashion for short, neat hair styles is a great help in this connexion.

The greatest advances will be made as hygiene improves and is learnt automatically in more and more homes and schools, so that when a boy or girl goes to a technical college and finally into a catering business, it will be unnecessary to teach such elementary rules.

The Hotel and Catering Institute has assumed responsibility for the setting up of classes for the training of students at colleges and educational institutes throughout Great Britain. It has a graded system of examinations, and the student can only progress into a higher grade when he has satisfied the examiners that he is proficient in all subjects. 